\title{
Characteristic analysis of sea transportation passenger Kendari Nusantara Port
}

\author{
La Welendo ${ }^{1,}{ }^{*}$, Usman Rianse ${ }^{2}$, Adris A Putra ${ }^{2}$ and La Hatani ${ }^{2}$ \\ ${ }^{1}$ Management Science Study Program, Halu Oleo University, Kendari, Southeast Sulawesi, Indonesia. \\ ${ }^{2}$ Halu Oleo University, Kendari, Southeast Sulawesi, Indonesia.
}

GSC Advanced Engineering and Technology, 2021, 01(02), 042-048

Publication history: Received on 26 June 2021; revised on 18 August 2021; accepted on 20 August 2021

Article DOI: https://doi.org/10.30574/gscaet.2021.1.2.0038

\begin{abstract}
Indonesia, which is an archipelagic country consisting of islands, sea transportation is an absolute necessity for those living in the archipelago. The port terminal is a tool for the process of moving goods and passengers to transfer modes of movement either through sea transportation or land transportation. The purpose of this study was to determine the characteristics of sea transportation users at the Kendari Nusantara port terminal. The method in this study uses a qualitative descriptive by distributing questionnaires to users of the Nusantara Kendari port terminal who want to travel between islands. The results of the study based on the characteristics of sea transportation users through the Kendari Archipelago port were obtained based on the characteristics of sea transportation users (passengers) at the port terminal.the male gender is $57.33 \%$, the most dominant travel destination is Muna Regency at $38.67 \%$, the reason for using fast express boats is the consideration of travel time by $52 \%$, the purpose of the trip is dominated by educational interests by $32.67 \%$, The frequency of using fast boats is very frequent, which is more than 4 times by $33.33 \%$
\end{abstract}

Keywords:Characteristics; Users; Ports; Sea transportation

\section{Introduction}

Nusantara Kendari Harbor is one of the passenger terminal ports for inter-island travel in Southeast Sulawesi. Geographically, it is located at $03^{\circ} 58^{\prime \prime} 25^{\prime \prime}$ South Latitude and $125^{\circ} 11^{\prime} 00^{\prime \prime}$ East Longitude. The role of the Kendari Archipelago port is very important because it is the main node of the economy and as an entry and exit route for goods and passengers across Southeast Sulawesi.

The development of the Kendari Archipelago port in general cannot be separated from the influence of the hinterland which can have direct access to the port such as transportation facilities, which connect areas within Kendari City as well as between regencies and between islands in Southeast Sulawesi. The Kendari Archipelago Port is one of the important and strategic aspects in facilitating the regional economy.

\section{Literature review}

\subsection{Transportation System}

Gottfried, B., S., 1984. Transportation is defined as the activity of moving goods and or people from one place to another using certain modes. So a complete transportation system can be defined as a collection of components whose interactions cause the movement of goods or people from one place to another.

${ }^{*}$ Corresponding authorLa Welendo

Management Science Study Program, Halu Oleo University, Kendari, Southeast Sulawesi, Indonesia.

Copyright (C) 2021 Author(s) retain the copyright of this article. This article is published under the terms of the Creative Commons Attribution Liscense 4.0. 
Miro (2012) in general, transportation can be interpreted as an effort to move or move people or goods from a location called the location of origin, to another location or destination, for certain purposes by using certain tools as well. Transportation has several dimensions such as: location (origin and destination), tools (technology), certain needs at the destination location such as social economy and others.

\subsection{Sea Port System}

Morlok, E., K., 1995, The sea port system is part of the marine transportation system. The sea transportation system itself can be defined as a system for the movement of goods or people from one place to another through marine facilities and infrastructure.

Triatmojo B., 2010, The port consists of several components that interact and form a system and is called a seaport system to distinguish it from an airport. The sea port system consists of 2 (two) main elements, namely elements of port facilities in the form of ships and infrastructure elements in the form of port facilities.

\subsection{Transportation User Characteristics}

(Morlok, 1991) The behavior of users of transportation modes is influenced by:

- Travel Characteristics Factor, variables that affect the behavior of users of transportation mode services in choosing a mode of transportation, namely: (a) Trip purpose such as work, school, social and others, (b) Time of trip made such as morning, afternoon day, midnight, holidays and others, (c). Trip length is the physical distance (kilometers) between origin and destination, including the length of the route.

- Traveler Characteristics Factor, variables that affect individual travelers, namely: (a). income, in the form of the traveler's purchasing power to finance his trip, (b). Car ownership, in the form of the availability of private vehicles as a means of traveling, (c) Condition of private vehicles (old, bad, new, etc.), (d). Density of settlements (density of residential development), (e). Other socio-economic factors, such as family structure and size, age, gender, type of work, job location.

- Transportation System Characteristics Factor, Variables that affect travel behavior in choosing transportation modes are related to the performance of transportation system services such as relative travel time, relative travel cost, relative level of service, accessibility, reliability.

- Special Characteristics Factor, Variables that affect the Special Characteristics Factor such asthe distance from residence to the place of activity. population density.

Manheim, (1979). Attributes for services in the field of transportation from various considerations of consumers have been formulated by These attributes are considered to represent services to consumers and affect each different consumer activity. Examples of attributes formulated by Manheim (1979) are as follows:

- Time whose indicators consist of total travel time, reliability (variation of travel time), transfer time, travel frequency and travel schedule.

- Costs whose indicators consist of direct transportation costs such as tariffs and fuel costs, indirect transportation costs such as maintenance and insurance costs.

- Safety and security whose indicators consist of the possibility of accidents and feelings of security.

- Pleasure and comfort of service users whose indicators consist of travel distance, physical comfort (temperature, cleanliness), travel pleasure (handling baggage, ticketing, food and drink services, other pleasures such as music entertainment).

- Expedition services in the form of loss insurance and return shipping rights.

\section{Methodology}

\subsection{Method Approach}

This study uses a descriptive qualitative method referring to literature references data collection in the field is carried out by observation and distributing questionnaires to users of sea transportation at the passenger port terminal at the port of Nusantara Kendari. (Nazir, 1999) random sampling analysis technique with the following equation:

$n=\frac{N}{1+N \cdot e^{2}}$ 
Where

$\mathrm{n}=$ number of questionnaire data

$\mathrm{N}=$ Number of users of inter-island sea transportation passengers

$\mathrm{e}=$ error value of data collection accuracy $(5 \%)$

\subsection{Research data}

The population in this study are users of passengers at the Nusantara Kendari port terminal who want to travel on sea voyages. Data from the survey results of passengers (users) at the Nusantara Kendari port terminal was carried out over a period of 1 month, with a total of 150 respondents.

\subsection{Data analysis techniques}

Data analysis is used in this study with a combination theory approach, namely calculations and graphs, in the form of calculated numbers and graph formulations.

\section{Results and discussion}

\subsection{Characteristics of users of the Kendari Nusantara port terminal}

\subsubsection{Gender}

Gender is a measurement tool for user travel characteristics to determine the percentage of users to gender, as for the gender of the users of the Kendari Nusantara ship port terminal as shown in table 1 below:

Table 1Gender

\begin{tabular}{|c|c|c|c|}
\hline Number & Variable & Total & Percentage \\
\hline 1 & male & 86 & $57,33 \%$ \\
\hline 2 & female & 64 & $42,67 \%$ \\
\hline \multicolumn{2}{|c|}{ Total } & 150 & $100 \%$ \\
\hline
\end{tabular}

Table 1. Users of express fast boat modes through the port of Nusantara Kendari by gender, male $57.33 \%$, female $42.67 \%$.

\subsubsection{By Age}

Based on the age of the users are sea transportation passengers who carry out the administrative process of sea trips at the Kendari Nusantara port terminal, which can be seen in table 2 below:

Table 2 Based on age

\begin{tabular}{|c|c|c|c|}
\hline Number & Variabel & Total & Percentage \\
\hline 1 & $<17$ Years & 6 & $4,00 \%$ \\
\hline 2 & 17 - 40 Years & 126 & $84,00 \%$ \\
\hline 3 & $>40$ Years & 18 & $12,00 \%$ \\
\hline \multicolumn{2}{|c|}{ Total } & 150 & $100 \%$ \\
\hline
\end{tabular}

Table 2 users of express fast boat modes through the Kendari Archipelago port by age, > 17 years 4\%, 17-40 years 84\%, and $>40$ years $12 \%$.

\subsubsection{Travel Destination}

The purpose of the trip is to find out the distribution of movement from origin to destination as shown in Table 3 below: 
Table 3 Based on Travel Destinations

\begin{tabular}{|c|l|c|c|}
\hline Number & Variable & Total & Percentage \\
\hline 1 & Muna District & 58 & $38,67 \%$ \\
\hline 2 & West Muna Regency & 12 & $8,00 \%$ \\
\hline 3 & South Buton Regency & 2 & $1,33 \%$ \\
\hline 4 & Wakatobi District & 4 & $2,67 \%$ \\
\hline 5 & Smelly City & 31 & $20,67 \%$ \\
\hline 6 & Buton District & 8 & $5,33 \%$ \\
\hline 7 & other & 150 & $23,33 \%$ \\
\hline Total & \multicolumn{2}{|r}{ Source: Data Analysis Results } \\
\hline
\end{tabular}

Table 3 Users of express fast boat modes through the port of Nusantara Kendari based on the purpose of the trip, Kab. Muna 38.67\%, Kab. West Muna 8.00\%, Kab. South Buton, 20.67\%, Kab. Wakatobi 20.67\%, Kota Baubau 20.67\% Kab. Buton 5.33\%, others $23.33 \%$.

\subsubsection{Based on Education}

Education is a characteristic part of human resources who want to travel as shown in Table 4 below:

Table 4 Based on Last Education

\begin{tabular}{|c|l|c|c|}
\hline Number & Variabel & Total & Percentage \\
\hline 1 & Primary school & 0 & $0,00 \%$ \\
\hline 2 & Junior high school & 0 & $0,00 \%$ \\
\hline 3 & Senior High School & 99 & $66,00 \%$ \\
\hline 4 & Diploma & 4 & $2,67 \%$ \\
\hline 5 & Bachelor & 31 & $20,67 \%$ \\
\hline 6 & Master & 11 & $7,33 \%$ \\
\hline 7 & Doctor & 150 & $3,33 \%$ \\
\hline Total & \multicolumn{2}{|c}{ Source: Data Analysis Results } \\
\hline
\end{tabular}

Table 4. based on the respondent's latest education, Elementary school 0\%, Junior high school 0\%, Senior high school 66\%, Diploma, 2.67\%, Bachelor 20.67\%, Masters 7.33\%, Doctoral/S $3.33 \%$.

\subsubsection{Based on Job}

Employment is how important the trip is based on the job as shown in the following table 5 below:

Table 5 Based on Occupation

\begin{tabular}{|c|l|c|c|}
\hline Number & Variabel & Total & Percentage \\
\hline 1 & civil servant & 18 & $12,00 \%$ \\
\hline 2 & State-owned enterprises/regional-owned enterprises & 6 & $4,00 \%$ \\
\hline 3 & Indonesian National Army/Republic of Indonesia Police & 1 & $0,67 \%$ \\
\hline
\end{tabular}




\begin{tabular}{|c|l|c|c|}
\hline 4 & Farmer & 2 & $1,33 \%$ \\
\hline 5 & entrepreneur & 10 & $6,67 \%$ \\
\hline 6 & Contract/Honorary Workers & 11 & $7,33 \%$ \\
\hline 7 & Student/Student & 102 & $68,00 \%$ \\
\hline 8 & Fisherman & 0 & $0,00 \%$ \\
\hline Total & & 150 & $100 \%$ \\
\hline
\end{tabular}

Table 5. Based on the work of respondents using terminal users via fast boat mode, namely civil servant $12 \%$, Stateowned enterprises/regional-owned enterprises 4\%, Indonesian National Army/Republic of Indonesia Police0.67\%, Farmer 1.33\%, Entrepreneurs 6.67\%, Contract/Honorary Workers 7.33 \%, Students/Students 68\%, Fishermen 0\%.

\subsubsection{Reasons for choosing fashion}

The choice of transportation mode on a trip where the port of Nusantara Kendari is a passenger port of fast express ships as part of the consideration of how important it is among transportation modes to travel by sea based on reasons for using fast boat modes as shown in the following table 6 below:

Table 6 Respondents' Perjans Based on Reasons for Using Fast Boat Mode Mod

\begin{tabular}{|c|l|c|c|}
\hline Number & \multicolumn{1}{|c|}{ Variable } & Total & Percentage \\
\hline 1 & Speed/time considerations & 78 & $52,00 \%$ \\
\hline 2 & Safety/security considerations & 12 & $8,00 \%$ \\
\hline 3 & Convenience considerations & 9 & $6,00 \%$ \\
\hline 4 & Consideration of convenience & 22 & $14,67 \%$ \\
\hline 5 & Price considerations (cheap) & 21 & $14,00 \%$ \\
\hline 6 & Other & 8 & $5,33 \%$ \\
\hline Total & & 150 & $100 \%$ \\
\hline
\end{tabular}

Table 6. on the reasons for using the fast boat mode, considerations of speed/time $52 \%$, considerations of safety/security $8 \%$, considerations of comfort $6 \%$, considerations of convenience $14.67 \%$, considerations of price (cheap) 14\%, Others $5.33 \%$.

\subsubsection{Respondent's Travel Purpose}

The purpose of passenger travel is a measurement of how important it is to travel by sea transportation mode, as for the purpose of passenger travel as shown in Table 7 below:

Table 7 Purpose of Travel

\begin{tabular}{|c|l|c|c|}
\hline Number. & \multicolumn{1}{|c|}{ Variable } & Total & Percentage \\
\hline 1 & Business / work & 17 & $11,33 \%$ \\
\hline 2 & Education & 49 & $32,67 \%$ \\
\hline 3 & Shopping & 0 & $0,00 \%$ \\
\hline 4 & Vacation / Recreation & 42 & $28,00 \%$ \\
\hline 5 & Other & 42 & $28,00 \%$ \\
\hline Total & \multicolumn{2}{|r|}{ Source: Data Analysis Results } \\
\hline \multicolumn{2}{|r|}{} \\
\hline
\end{tabular}


Table 8. Regarding the respondents' travel intentions, 17 people work/work or $11.33 \%$, education $32.67 \%$, $0 \%$, vacation/recreation $28 \%$, Others $28 \%$.

\subsubsection{By Trip Frequency}

The frequency of user trips which is part of the consideration of how important the travel cycle through sea transportation modes through the Nusantara port is to measure the transfer of transportation modes as for the frequency of passengers through the Kendari Nusantara port as in Table 8 below:

Table 8Frequency of trips

\begin{tabular}{|c|l|c|c|}
\hline Number & \multicolumn{1}{|c|}{ Variable } & Total & Percentage \\
\hline 1 & the first time & 30 & $20,00 \%$ \\
\hline 2 & twice & 46 & $30,67 \%$ \\
\hline 3 & third time & 16 & $10,67 \%$ \\
\hline 4 & fourth time & 8 & $5,33 \%$ \\
\hline 5 & more than four times & 50 & $33,33 \%$ \\
\hline Total & \multicolumn{2}{|c|}{ Source: Data Analysis Results } \\
\hline \multicolumn{2}{|r|}{} \\
\hline
\end{tabular}

Table 8. on the frequency of passengers using the fast boat mode, 1 time 20\%, $230.67 \%$, 3 times $10.67 \%$, 4 times $5.33 \%$, more than 4 times $33.33 \%$.

\subsubsection{Based on Income}

The income of sea transportation users is measured how important it is for travelers to use sea transportation modes based on economic considerations as for user income as shown in the following table 9 below:

Table 9 User income

\begin{tabular}{|c|l|c|c|}
\hline Number & \multicolumn{1}{|c|}{ Variable } & Total & Percentage \\
\hline 1 & < Rp. 1.000.000,- & 99 & $66,00 \%$ \\
\hline 2 & Rp. 1.000.000 - Rp 1.500.000,- & 10 & $6,67 \%$ \\
\hline 3 & Rp. 1.500.000-Rp.2.500.000,- & 5 & $3,33 \%$ \\
\hline 4 & > Rp. 2.500.000,- & 36 & $24,00 \%$ \\
\hline Total & Source: Data Analysis Results & 150 & $100 \%$ \\
\hline
\end{tabular}

\section{Conclusion}

Characteristics of users (passengers) of sea transportation at the port terminalthe most dominant is the male gender by $57.33 \%$, the age of the passengers is dominated by the age of $17-40$ years $84 \%$, the highest travel destination is Muna Regency at $38.67 \%$, the activity or work is dominated by students at $68 \%$, the reason for using express fast boats is the consideration of travel time by $52 \%$, the purpose of travel for educational purposes is $32.67 \%$, the frequency of travel using fast boats through the port of Nusantara Kendari is very frequent, which is more than 4 times by $33.33 \%$. User income is less than Rp. 1,000,000 by $66 \%$,

\section{Recommendations}

The determination of the characteristics of inter-island sea transportation passengers is based on the reasons for using this mode of transportation. It is hoped that further research can analyze a more comprehensive sea transportation development model in determining the performance of inter-island sea transportation services. 


\section{Compliance with ethical standards}

\section{Acknowledgments}

Thank you to the operational officers of the Nusantara Kendari port for providing supporting data information in this study. Hopefully this research can be useful for the development of science and technology.

\section{Disclosure of conflict of interest}

There is no conflict of interest in this research.

\section{References}

[1] Arikunto S. Research Procedure, PT RinekaCipta Publisher, Jakarta. 1998.

[2] Antonius S, et al. Performance of Trans Maluku Crossing Transportation in Supporting Community SocioEconomic Activities. International Journal of Civil and Environmental Engineering, IJCEE/IJENS. 2012;24(4).

[3] Dwi EI, et al. Performance Study of Pioneer Transportation Services for the Tunda-Karangantu Island Crossing. Technical Journal. 2019;15(1): 49 - 61.

[4] Efendi S. Survey Research Methods, Publisher PT Pustaka LP3ES Indonesia, Jakarta. 1995.

[5] Fita K. Strategy to Improve Sea Transportation in the Thousand Islands in the Perspective of Integrated Coastal and Marine Area Development System. Balitbang Transportation. 2010;22(8).

[6] Franky KS, et al. Implementation of the Development of the Sea Toll Road to Realize Indonesia as the World Maritime Axis. Journal of Maritime Security. 2018;4(1).

[7] Gottfried BS. Elements of Stochastic Process Simulation, Prentice Hall, Inc., New Jersey. 1984.

[8] Hariastuti NLP, et al. Improving the Quality of Service to Customers at the Passenger Terminal of Tanjung Perak Port Surabaya. 2013.

[9] Ibrahim A. Theory and Concept of Public Service and Its Implementation. Bandung: Forward Mandar. 2008.

[10] Imam S, et al. Potential Center for Consolidated Freight for the Asia Pacific Region, Journal of Marine Transport Research. 2018.

[11] Ismadarni. Study of the Characteristics of Travelers in the West Palu District Zone, Palu City, Central Sulawesi, Smartek Journal: Department of Civil Engineering, Tadulako University, Palu. 2010.

[12] Jayadinata T. Johara. Land Use in Urban and Regional Rural Planning. Bandung: ITB. 1999.

[13] KramadibrataS. Port Planning, Ganeca Exact Bandung. 1985.

[14] Manheim MI. Fundamentals of Transportation system analysis, volume I: Basic Concepts, The MIT Press, Cambridge. 1979.

[15] Milisan J. Service Level Analysis of Terminal Passenger on Balikpapan Port. 2017.

[16] Miro F. Introduction to Transportation Systems. Jakarta: Erlangga. 2012.

[17] MorlokEK. Introduction to Transportation Engineering and Planning. Erlangga, Jakarta. 1995.

[18] Nazir. Research methods, Ghalia. Jakarta. 1999

[19] Welendo La, et al. Model Of Inter Island Sea Transportation Selection In Southeast Sulawesi, International Journal of Applied Mathematics \& Statistical Sciences (IJAMSS). 2021; 10(1). 